Meta

Journal des traducteurs

Translators' Journal

\title{
Science of Translation Today: Change of Scientific Paradigm
}

\section{Nikolay Garbovskiy et Olga Kostikova}

Volume 57, numéro 1, mars 2012

La CIUTI, chef de file pour la promotion de l'employabilité et de la recherche

CIUTI: Leader in Advocating Employability and Research

URI : https://id.erudit.org/iderudit/1012740ar

DOI : https://doi.org/10.7202/1012740ar

Aller au sommaire du numéro

\section{Éditeur(s)}

Les Presses de l’Université de Montréal

ISSN

0026-0452 (imprimé)

1492-1421 (numérique)

Découvrir la revue

Citer cet article

Garbovskiy, N. \& Kostikova, O. (2012). Science of Translation Today: Change of Scientific Paradigm. Meta, 57(1), 48-66. https://doi.org/10.7202/1012740ar
Résumé de l'article

L'article traite de l'état actuel des recherches traductologiques en Russie dans une perspective historique. Il est apparu comme une réaction à une représentation qui reste ancrée dans l'esprit scientifique en Russie sur le statut secondaire des recherches traductologiques souvent réduites à une branche appliquée de la linguistique. La discipline n'aurait pas d'existence propre, car elle serait diluée dans un continuum pluridisciplinaire, surtout parce qu'elle ne pourrait établir de paradigmes scientifiques spécifiques. Nous examinerons la validité de cette opinion, nous tournant, pour cela, vers l'histoire de la pensée scientifique sur l'activité traduisante, puis en analysant l'état actuel de la discipline nommée aujourd'hui « science de la traduction » en Russie. L'article a deux objectifs interreliés : d'une part, prouver l'existence de paradigmes traductologiques en Russie et, d'autre part, caractériser l'état actuel des recherches en traductologie en Russie selon une perspective historique tout en démontrant leurs liens avec le contexte international des recherches dans ce domaine. 


\title{
Science of Translation Today: Change of Scientific Paradigm
}

\author{
NIKOLAY GARBOVSKIY \\ Lomonosov Moscow State University, Moscow, Russia \\ garok1946@mail.ru
}

\section{OLGA KOSTIKOVA}

Lomonosov Moscow State University, Moscow, Russia olga.kostikova@list.ru

\begin{abstract}
RÉSUMÉ
L'article traite de l'état actuel des recherches traductologiques en Russie dans une perspective historique. II est apparu comme une réaction à une représentation qui reste ancrée dans l'esprit scientifique en Russie sur le statut secondaire des recherches traductologiques souvent réduites à une branche appliquée de la linguistique. La discipline n'aurait pas d'existence propre, car elle serait diluée dans un continuum pluridisciplinaire, surtout parce qu'elle ne pourrait établir de paradigmes scientifiques spécifiques. Nous examinerons la validité de cette opinion, nous tournant, pour cela, vers l'histoire de la pensée scientifique sur l'activité traduisante, puis en analysant l'état actuel de la discipline nommée aujourd'hui «science de la traduction» en Russie. L'article a deux objectifs interreliés: d'une part, prouver l'existence de paradigmes traductologiques en Russie et, d'autre part, caractériser l'état actuel des recherches en traductologie en Russie selon une perspective historique tout en démontrant leurs liens avec le contexte international des recherches dans ce domaine.
\end{abstract}

\begin{abstract}
The present article is devoted to analyzing the present state of the Russian science of translation and its historical perspective. The rationale behind this article is the fact that in Russian academic community there is a persisting viewpoint that research in translation studies is an auxiliary and applied area of linguistics and that science of translation does not exist at all because it is diluted in pluridisciplinary continuum and, which is essential, does not have scientific paradigms. We will attempt to understand whether this opinion is true, and in order to do it we will examine history of scientific knowledge about translation activity and analyze the present state of the discipline that is known at present as "science of translation" in Russia. Thus, the article addresses two intertwined tasks: to prove that Russian theory of translation has scientific paradigms and to characterize research in translation studies in Russia in historical perspective and demonstrate its close interrelation with science of translation in the world.
\end{abstract}

\section{MOTS-CLÉS/KEYWORDS}

science de la traduction, stade empirique, stade théorique, interdisciplinarité, approche cognitive

science of translation, empirical stage, theoretical stage, interdisciplinarity, cognitive approach 


\section{Introduction}

Some contemporary philologists in Russia do not consider translation studies (perevodovedenie in Russian) to be a scientific discipline because, in their opinion, it does not have scientific paradigms. By scientific paradigms one usually means that there is a dominating approach or a point of view on the studied object.

Let us try to understand how true this opinion is by referring to the history of scientific knowledge about translation activity and by analyzing the current state of science of translation.

First of all, it is necessary to clarify the term that refers to the science.

\section{Substantiation of the term}

In the English-speaking tradition there is a term translation studies, which generally means an academic discipline that deals with studying translation. It has been known under different names. Some scholars referred to it as science of translation, others as translatology (traductologie in French), however, the term translation studies is the one most widely used nowadays. In his article The name and nature of translation studies, James S. Holmes (Holmes 1972) advocated this term for the academic discipline as a standard term for this field in general and other scholars followed him. However, the term translation studies mostly referred to research in literary translation; other forms of translation, including simultaneous interpretation, were taken into account to a lesser degree, and practical activity, e.g., translation teaching, was largely overlooked.

Nevertheless, this situation did not last long. At present, translation studies is considered to be a discipline that studies translation in general, including literary translation and other types of translation, interpretation, dubbing and subtitling. Due to the existence of this term the words translation and translator are used as generic terms. Translation studies also cover a wide range of research and teaching from general theoretical framework to specific applied research including translator training and assessment criteria.

In the French language, the term traductologie appeared in 1972 in the works by Harris, a Canadian scholar (Harris 1972: 69; however, in this article, he refers to Goffin's proposition, which was actually traductiologie; see Goffin 2006). Some scholars underline that traductologie was preferred by Ladmiral and Berman (OsekiDépré 1999: 7). Awaïss (2006: 14) posed a question whether this term covered new terms denoting old notions, whether Harris had found new labels for old practices and old concepts. Bocquet (2006: 32) reflected whether it is possible to use the term translation with double meaning: translation proper and the discipline that studies it. Meanwhile, "la traductologie" progressed greatly in France over these forty years. Ladmiral in his works on "traductologie" developed epistemology of the field, singled out translation studies dichotomies and convincingly proved that "traductologie" is not an applied field of linguistics, but a separate multidisciplinary area of research. Ladmiral described its metamorphoses using the metaphore of ages: "les quatre âges de la traductologie": prescriptive, descriptive, productive et inductive (Ladmiral 1997; 2004b). Which of them is golden? This question still has no answer, and the question "Qu'est-ce que la traductologie?" is still on the agenda of conferences gathering experts who try to find the answer (see Ballard 2006). 
In the Russian language at present three terms are widely used: teoria perevoda (theory of translation), perevodovedenie (translation studies) and nauka o perevode (science of translation). In some cases perevodovedenie denotes a number of academic disciplines studying various aspects of translation, e.g., there are linguistic, psychological, literary, ethnographic and historical translation studies. Some contemporary researchers define perevodovedenie as "a science that is creating theory of translation" (Tulenev 2004: 6), whereas others as "all the fields of research that study translation as a process and as a result" (Alekseeva 2004: 3); however sometimes the terms teoria perevoda and perevodovedenie are used equally (Alekseeva 2004; Komissarov 2001; Sdobnikov et Petrova 2007; Toper 2000).

However, most contemporary works are starting to make a wider use of a generic term that covers a range of scientific knowledge on translation and all research of translation activity in general, i.e. its linguistic, cultural and anthropological, sociological, psychological, philological and other aspects, and this term is nauka o perevode (science of translation; Fjodorov 2002; Garbovskiy 2004; Garbovskiy, Kostikova et al. 2010; Komissarov 2001; Nelubin et Huhuni 2006; Tulenev 2004).

In our opinion, this term is the best for two reasons at least. Firstly, it reflects in most general terms the interdisciplinary character of research in translation activity and does not emphasize any of its many aspects. In the framework of this science, translation is studied as a cognitive activity using methods and tools of all cognitive disciplines that cover collecting, processing, recording, storing, organizing, accumulating and applying data and knowledge of the world by human brain using sign systems and their interpretation and evaluation, which is in line with the global trends in the field (Bell 1991; Černov 1978; Krings 1986; Lee-Jahnke 2005; 2010; Širjaev 1979; Tirkkonen-Condit 1989; Wu 2002). Therefore, translation is regarded as an activity that means collecting, processing, recording, storing, organizing, accumulating and applying information, its interpretation, evaluation and recoding it into a different sign system with the purpose of conveying it, and the global structure of this activity, as that of any other, involves the goal, the means, the result and the process itself (Judin 1978: 268). Thus, the sphere of research becomes much broader.

Secondly, the term translation in this case is regarded as a generic term for translation activity as a whole, without subdividing it into specific types depending on written or oral manifestation, which is in line with Russian tradition in this field. The single term for both oral and written types of translation activity provides great opportunities for searching a common foundation for any type of translation regardless of conditions and methods of carrying it out. This common ground does not only unite all types of translation activity, but also distinguishes translation from other types of interlanguage mediation.

This is the meaning of the term science of translation in the present article. Now let us examine the stages of scientific knowledge development in this field. Every scientific theory usually has three stages of development:

- the empirical stage that is limited to classification and generalization of experimental data;

- the transitional stage, when primary theoretical models and methods are formed;

- the theoretical stage, when the theory of the object able to reflect its essence in an abstract way is developed. 
Science of translation as any scientific knowledge also went through several stages before becoming a scientific discipline that has object and subject and its own system of concepts and terminology.

\section{Empirical stage}

Science of translation began with the empirical stage when translation experience was generalized for the first time and first typologies were created. The empirical stage of Western science of translation began on the eve of the Common Era with Cicero's observations of his own translation experience that were expressed in the treatise De optimo genere oratorum (Steiner 1978: 224). The Roman orator managed to give the first known European typology of translation strategy laconically, just in one paragraph; he contrasts the translator-writer strategy and the translator-copyist strategy. Analyses of his own translation experience allowed Cicero to bring forward a number of interesting and revolutionary ideas of the interpretative nature of translation, which is manifested in the priority of meaning in translation, in following target language norms and in considering the source text as a material for creating a new text in the target culture.

Cicero was followed by numerous humanists, writers and poets, philosophers and theologians, public figures and tsars, who analyzed translation experience, shared their observations, criticized translations and taught translators for two thousand years.

At this stage, first categories and first oppositions of science of translation appeared. Dante and Du Bellay showed the dialectical nature of the category of translatability; they proved that attempts to translate poetry were pointless; however, they did not deny the possibility of translating texts of other types. Montesquieu vividly demonstrated what translation equivalence was, he wrote,

[l]es traductions sont comme ces monnaies de cuivre qui ont bien la même valeur qu'une pièce d'or et même sont d'un plus grand usage pour le peuple; mais elles sont toujours faibles et d'un mauvais aloi. (Montesquieu 1875: 269-270)

German romanticists revealed hermeneutic nature of translation and introduced the category of "the own" and "the foreign" by analyzing the perception of "the foreign" through translation. Russian poets laid the ground for the methodology of translation: V.K. Trediakovsky experimented with poetic forms in translation, poetstranslators V.A. Zhukovsky, N.I. Gnedich, P.A. Katenin and A.S. Griboyedov launched a discussion aimed at finding ways to communicate genre peculiarities of the original text.

On this stage the scientific knowledge tends to assume a prescriptive character (see Ladmiral 1996; Oseki-Dépré 1999). Previous experience was summarized and analyzed, primarily in order to teach how to translate and to avoid mistakes. L. Bruni (Italy), E. Dolet (France) and A. Tytler (England) wrote treatises, theologian M. Luther (Germany) and Russian poet A.P. Sumarokov (Sumarokov 1957) wrote letters and epistles on how to translate; and Russian Tsar Peter the Great following educational traditions dating back to enlightened sovereigns (e.g. Charlemagne, Charles the Bold and Charles the Wise in France, Alfred the Great in England, Alfonso X in Spain, caliph Al-Mamun in Baghdad, Yaroslav the Wise in Russia) did not only write letters to translators, but he also issued decrees on how and what to translate, 
I enclose the book by Pufendorf that contains two treatises: the first one on duties of man and citizen and the second one on the Christianity; but I demand that you translate only the first one, because I do not think the second one will be of much use. ${ }^{1}$ (Order to the Synod of 11 September 1724, cited in Kostikova 2009: 5; translated by the authors)

[...] when translating this book, you need to be careful and seek to translate as clearly as possible, especially those parts that teach how to do things; you do not have to preserve the wording in translation, but to understand the sense and to write in your own language in the clearest way possible. ${ }^{2}$ (Order to Zotov On avoiding mistakes in the future, 25 February 1709; translated by the authors)

In Peter's educational and translation activity, translation teaching was emphasized. The tsar demanded that a lot of works in foreign languages were translated in a short period of time and gave instructions how to translate, but also how to teach translators,

[w] need translators to translate books, especially art works because no translator will be able to translate if he does not know the art he translates about; that is why it is necessary to proceed in the following way: those who know languages but do not know arts have to learn arts, those who know arts but do not know languages have to learn languages... Arts include the following: mathematics and mechanics, surgery, civil architecture, anatomy, botany, military and others. ${ }^{3}$ (Decree of 23 January 1724; translated by the authors)

Peter's initiative was developed by the Russian empress Catherine the Great who established the first professional community of translators in Russia, the Assembly seeking to translate foreign books into Russian (Sobranie, staraučšeesja o perevode inistrannyh knig na rossijskij yazyk). Under her rule, translation activity flourished and translators called this period the "golden age of translation."

Translation debates in Russia were no less heated. In the $18^{\text {th }}$ century poetic contests were organized that aimed to address translation tasks proper (to find new forms of expression and, as a result, to develop the Russian language) as well had didactic and "ludic" functions. Lomonosov and other famous poets of that period participated in poetic translation competitions and made a significant contribution into the development of the Russian language. The best-known competition is translation of Psalm 143 in which Lomonosov, Trediakovsky and Sumarokov took part. The poetic competition went on in translating an ode by the French poet Jean-Baptiste Rousseau (1670-1747). In the January volume of Poleznoe Uveselenie [Distraction instructive] journal published by Moscow University, two poems were published under the title:

Ode by Mr Rousseau Fortune de qui la main couronne, translated by Mr Sumarokov and Mr Lomonosov. Amateurs and those who know literary arts can determine themselves to whom these translations belong according to the style peculiarities of each poet. ${ }^{4}$ (Poleznoe Uveselenie January 1760; translated by the authors)

Sumarokov used trochee in his translation, whereas Lomonosov used iambus. Later this contest was joined by Trediakovsky who included his translation of this ode by Rousseau into the 12th volume of his translation of Roman History by Charles Rollin (1765).

In the 19th century translators' debates of the Pushkin period had huge repercussions; at that time interest in literary translation was revitalized. Journals of that 
period are full of articles and comments on published translations; translators often included prefaces to their translations in which they defined their own viewpoint and argued with their opponents. It is perhaps for the first time that in Russian press some translation problems were clearly outlined and they are still topical, it is the issue of accuracy or, according to Pushkin, fidelity of literary translation, the issue of conveying the prosodic form of the original, of translating trite metaphors and idioms, of the category of national identity and its preserving in translation.

The intensity of these debates signifies that the issues they touched upon were of professional interest, but also that they were closely related to everyday life in that period. These discussions were completed in the article by Pushkin On Milton and Translation of Paradise Lost by Chateaubriand written in 1836 and published after his death in 1837. The article is widely known in Russia and it was repeatedly quoted in Soviet works on theory and history of literary translation.

Scientific knowledge on translation at that period was advanced by considerations of writers and philosophers who criticized results of translators' activity.

\section{Transitional stage}

By the early $20^{\text {th }}$ century the empirical stage of the science of translation had become the transitional stage that preceded the theory of translation. Generalization of empirical experience in the field of translation activity gained critical mass, i.e. it became sufficient for primary theorizations and for first theoretical constructs. At this stage science of translation remained prescriptive (see Ladmiral 1997). Note that, for many scientists, the $20^{\text {th }}$ century is the starting point for the emergence of the science of translation in the strict sense. (Komissarov 2004; Garbovskiy and Kostikova 2011).

In Russian science of translation of this period, prescriptive character is especially evident; moreover, it has a two-level structure. The transition to the stage of constructing first theories coincided with the revolutionary changes in social life. The October Revolution created a new type of mass reader who needed new translations.

M.A. Gorky gathered well-known writers and philologists in his publishing house Vsemirnaja Literatura founded in 1918. Its explicit objective was to

raise the level of translation art and train young translators who could provide the best books on earth to the new Soviet reader who gets acquainted with cultural heritage of all periods and peoples. ${ }^{5}$ (Čukovsky 1968: 6; translated by the authors)

In order to improve translation skills and quality of translation a theory was necessary to «arm a translator with simple and clear principles, so that every translator, even an ordinary one, could improve his skills"6 (Čukovsky 1968: 6; translated by the authors). Gorky insisted on creating such a theory.

Thus, creating a translation theory (prescriptive character of the first level) was not a natural consequence of the accumulation of sufficient empirical evidence, but an act of will (prescriptive character of the second level).

In 1919, the brochure Principles of Literary Translation was published; it included articles by K.I. Čukovsky and N.S. Gumilev. It was the first attempt to create a theory which enabled to make new translations "on the other, strictly scientific, basis that 
excluded former methods of unprincipled primitive work"7 (Čukovsky1968: 6; translated by the authors). In 1936, the book Art of Translation by Čukovsky was published. The editor's foreword said that,

[T] he theoretical development of literary translation issues has just begun [...]. Probably, a number of statements and estimations of K.I. Chukovsky will spark debate, but discussions that may arise on this basis will play their positive role in promoting the development of a new, not yet developed field of the theory of literature. ${ }^{8}$ (Anonymous foreword, in: Čukovsky 1936; cited in Čukovsky 1968: 381; translated by the authors).

The theory of literary translation was gaining its place in literary studies. However, it mainly took into account literary translation, so it was too early to speak of a general theory of translation. Theoretical considerations that were undoubtedly sophisticated and valuable not only for young translators, but also for those who reflected on the phenomenon of translation, were based on critical analysis of translations.

Works by M.P. Alekseev (1931), E.I. Galperina (Gal 1972/2007), G.R. Gachechiladze, I.A. Kashkin, Yu. D. Levin, N.M. Ljubimov (1977), P.M. Toper (2000), A.V. Fjodorov (1953; 1973; 2002), K.I. Čukovsky (1936; 1968), E.G. Etkind (1959; 1970) and others formed a theoretical approach to literary translation in Russian science, its possibilities and limits. Researchers looked for methods and forms that would allow a translator to convey the main component of the text, i.e. its spirit.

Thus, the first paradigm of science of translation, the literary critical paradigm, was established.

However, a scientific revolution was maturing within this paradigm. In 1953, A.V. Fjodorov published his work Vvedenie $v$ teoriu perevoda, which announced that a new field of scientific knowledge, linguistic theory of translation, i.e. a new scientific paradigm, was born (Fjodorov 1953). It was a real revolution in science of translation with all characteristics of a revolution: advocates of the old paradigm fiercely opposed the new idea and tried to prove its inconsistency, while innovators actively promoted the new idea, which was not confirmed by experimental evidence yet.

Theory of translation sought to go beyond literary studies. The literary critical approach to translation with uncertain categories and subjective assessments had to give way to another one that was more rigorous and based on studying language means of expression. Fjodorov wrote:

All sorts of studies and discussions about how translation reflected original content and what role it played for literature will be pointless unless they are based on an analysis of linguistic means of expression used in translation. ${ }^{9}$ (Fjodorov 1953: 14; translated by the authors)

The objective of this discipline was seen in

[...] generalizing findings from observations of individual cases of translation and serving as a theoretical foundation for translation practice that could be guided by it in looking for needed means of expression and choosing them, and could turn to it for arguments and evidence in favour of specific solutions. ${ }^{10}$ (Fjodorov 1953: 12; translated by the authors)

Fjodorov insisted that science of translation had a linguistic character rather than a literary one: 
Linguistic approach to the study of translation has the major advantage that it touches upon its very foundation, the language, without which no translation function exists, neither its social and political role, nor cultural and cognitive one, nor its artistic value, etc. ${ }^{11}$ (Fjodorov 1953: 14; translated by the authors)

Revolutionary character of Fjodorov's work consisted in an attempt to give science of translation clearer boundaries by defining its subject. It was linguistics that seemed to be an exact discipline that could generalize empirical views on translation and summarize previous observations of specific translation experiences.

Not only translation researchers, but also other scholars who studied the human being, turned to linguistics and its exact methods introduced by the structuralists at that period. It is enough to remember the presentation of Claude Lévi-Strauss, French philosopher and anthropologist, at the anthropology conference in Bloomington in 1952, subsequently published in his famous work Structural Anthropology:

[1]a linguistique occupe cependant une place exceptionnelle: elle n'est pas une science sociale comme les autres, mais celle qui de loin, a accompli les plus grands progrès; la seule sans doute, qui puisse revendiquer le nom de science et qui soit parvenue, à la fois, à formuler une méthode positive et à connaître la nature des faits soumis à son analyse. [...] Elle se doit aussi d'accueillir les psychologues, sociologues et ethnographes anxieux d'apprendre de la linguistique moderne la route qui mène à la connaissance positive des faits sociaux. (Lévi-Strauss 1958/1974: 37)

It seemed that the application of linguistic methods would help to find objective and evidence-based guidelines "that would eliminate the subjective arbitrariness of a translator and references to 'intuition' as a justification of translator's arbitrariness"12 (Fjodorov 1953: 12; translated by the authors).

Mounin, analyzing some issues of American linguistics, admitted that the idea of a direct link between the system of significations of any language and ethnography of the community speaking the language was not new. However, he said:

[...] ce nouveau truisme apparemment improductif en linguistique est, lui aussi, productif dans une théorie de la traduction, parce qu'il ouvre une voie d'accès, très mal explorée jusqu'ici, vers les significations. (Mounin 1963: 234)

Mounin added that even translators of the ancient period followed by the E. Dolet and others argued that in order to convey the meaning it was not only knowledge of words, but also knowledge of the discussed subject that was necessary. According to Mounin, these ideas brought Edmond Cary, French simultaneous interpreter, who reflected on the essence of translation, to the conclusion that translation is not a linguistic operation, but the operation on phenomena associated with the cultural context as a whole. Mounin tentatively corrected his colleague, he wrote:

C'est l'idée - partiellement juste, on le voit - qui pousse Edmond Cary à soutenir que la traduction n'est pas une opération linguistique (alors il aurait raison s'il disait: n'est pas une opération seulement linguistique); mais qu'elle est une opération sur des faits liés à tout un contexte culturel (il aurait donc plus raison de dire: une opération sur des faits à la fois linguistiques et culturels, mais dont le point de départ et le point d'arrivée sont toujours linguistiques). (Mounin 1963: 234)

This idea has a lot in common with Fjodorov's statement about linguistic dominance in science of translation, who wrote: 
[s]ince translation always deals with the language and always means working with the language, it always requires the linguistic approach, i.e. connected with the nature of the relations between the two languages and their stylistic means. ${ }^{13}$ (Fjodorov 1953: 13; translated by the authors)

Linguistic science was not very enthusiastic about the birth of a new scientific paradigm in translation studies. Fjodorov had to argue with A.A. Reformatsky, wellknown linguist, who wrote in his article Lingvističeskie voprosy perevoda (Reformatsky 1952):

Such science cannot exist. Translation practice may make use of a lot of sciences, but it cannot have its own science. This stems from a variety of types and genres of translation. ${ }^{14}$ (Reformatsky 1952: 14; translated by the authors)

This point of view is interesting from two perspectives. Firstly, it justly emphasizes that translation may be an object of a variety of sciences (not only linguistics or literary studies). Secondly, Reformatsky draws attention to the variety of translation.

Reformatsky refers to interdisciplinarity to explain why theory of translation cannot be an independent field of scientific research. Nowadays interdisciplinarity is seen as a quite normal and, moreover, a necessary condition of objective scientific research. It is even more important when it comes to such a complex and diverse phenomenon as translation. But at that time the subject of linguistics was clearly limited by the boundaries of studying language systems. Translation is a phenomenon of speech, and speech was studied by stylistics. Orthodox linguistics was also reluctant to recognize it. It is to be noted that in Vvedenie $v$ yazykovedenie, well-known textbook by Reformatsky (Reformatsky 1947/2006), there is no section devoted to stylistics. For this scholar, stylistics is an individual choice mainly in the art of literature. Indirect proof can be found in the section where Reformatsky speaks about phraseology:

You can study phraseology of romanticism, sentimentalism, and naturalism, phraseology of Gogol, Herzen and Chekhov. Since such a study does not only describe the presence of specific facts, but also raises the question of choice and usage of vocabulary, it refers to stylistics. ${ }^{15}$ (Reformatsky 1947/2006: 132; translated by the authors).

It is within the framework of stylistics that the Russian linguistic science of translation developed throughout fifty years, seeking to explain the translator's choice by the nature of relationship between different languages, texts, discourses, and literatures. Comparative stylistics was the basis of translation theory of that time, which led to the creation of contemporary translation studies. Indeed, the first works on translation theory were obviously focused on comparative stylistics. A.V. Fjodorov noted that study of translation should be conducted "in connection with the character of correlation between the two languages and their stylistic devices"16 (Fjodorov, 1953: 13; translated by the authors).

The first major theoretical works on translation by foreign authors were called comparative stylistics. These are Stylistique comparée du français et de l'anglais by Canadian scholars J.P. Vinay and J. Darbelnet (1958) and Stylistique comparée du français et de l'allemand by Swiss linguist A. Malblanc (1961).

Thus, in the second half of the $20^{\text {th }}$ century, reluctantly and with many reservations, linguistics acknowledged translation studies, which can be compared to adopting a stepdaughter when there is no way to avoid that. 
The linguistic paradigm began to form in translation studies.

The linguistic paradigm, which replaced the literary critical one, allowed going beyond the limits of literary translation and expanding the field of research. In Vvedenie $v$ teoriu perevoda special chapters cover the general objectives of working on the language in translation as well as varieties of translation depending on the genre type of translated material (Fjodorov 1953: 334-335).

With its development, prescriptivity, i.e. a wish to elaborate recommendations for translation practice, to prescribe how to translate, gave way to a more systematic and comprehensive analysis of translation activity involving methods of other sciences, including psychology, philosophy, sociology, and ethnography. When he was already 80 years old, Fjodorov wrote:

The practical importance of this theoretical science consists, of course, not in advice or, even worse, recipes and directions to translators; it can be helpful for them in a different way, only indirectly, i.e. by revealing the diversity of relations between different languages and literatures, the variety of stylistic options and the richness of the language of translation, the breadth of means from which a translator can choose, and by pointing out the negative effect of word-for-word reproduction of the original's special linguistic features, the interconnection and the difference between the methods of translation and those of original creative work, and many other things. ${ }^{17}$ (Fjodorov 1973: 49; translated by the authors)

As if answering questions of a lot of professional translators, Fjodorov pointed out that theory of translation was not supposed to give direct advice, recommendations or instructions. Theory of translation lost its prescriptive character as it developed.

In the aforementioned quotation, which defines the practical importance of science of translation, the emphasis is made on the language. Fjodorov particularly stressed the relations between different languages and literatures, the diversity of stylistic options and the richness of expressive means of the target language. But as far as the essence and the practical importance of science of translation are concerned, a view on translation work as a social phenomenon, i.e. socially important and socially conditioned, became quite apparent (Garbovskiy 2004).

The fact that translation is a social phenomenon does not need proving. Paraphrasing the famous dictum of the ancient philosopher, we can say that a translator is a social creature. Translation originated in the human society when first groups of people settled across regions and continents and it became an essential phenomenon in human life. The society used translation and at some point started to wonder whether it satisfied their needs or not, began to critically assess translation work and to prescribe translators the rules of "good" translation, thus expressing their expectations of translated messages.

The socially important function of translation theory is to use its own methods to reveal the essence of the interaction between an individual translator and all public institutions, actants and objects involved in the process of intercultural, interethnic and interpersonal communication. This function is more important, but at the same time, less tangible. Translation theory does not directly teach "how to translate"; it suggests that translators should think about what they do, how they do it and why. 


\section{Toward the third stage of the theory}

For a long time science of translation focused on linguistic aspects of translation, on the analysis of relations between languages in translation and on the linguistic dominance of translation solutions.

Later attempts to go beyond linguistics and to examine translation experience from the perspective of cultural anthropology generated a lot of works on comparative culture studies. The connection between linguistic signs and cultural phenomena hidden behind them is obvious. Translational decoding of symbols denoting cultural phenomena of another ethnic group is impossible without the knowledge of this ethnic group. Translational expression of foreign cultural phenomena with target language signs is impossible without comparison between "ethnically foreign" and "ethnically own." This axiom gave rise to a lot of research works in the field of translation, diverse in their form, geography and time, which enhanced knowledge of comparative cultural anthropology of specific pairs of languages and specific ethnic communities that speak these languages. Unfortunately, these studies hardly made any contribution to understanding the essence of translation work as a socially meaningful activity and to realizing not only linguistic but also social reasons for translator's behaviour, which is, one way or another, always assessed by the society.

Researchers paid special attention to difficulties of translating so-called realia, i.e. various phenomena that are alien to the target culture. Comparative cultural research of realia expanded empirical knowledge of translation, but at the same time has failed to create a coherent scientific theory because of the complexity and diversity of objects under study and uniformity of approaches to studying them. However, it greatly expanded the research field of science of translation, diverting it from a narrowly linguistic perspective.

Cognitive linguistics, speech act theory and information theory brought science of translation to a higher level of theorizing. The interest in relatively new types of translation, in particular in simultaneous interpretation and its comparison with more traditional consecutive interpretation, as well as the need for algorithms for machine translation, prompted psychologists, biologists, medical doctors, computer science specialists, mathematicians and logicians to study translation. Researchers were mainly interested in translation mechanism and in the processes occurring in a translator's brain in various socially and psychologically determined conditions (Bell 1991; Černov 1978; Danks, Shreve et al. 1997; Gambier, Gile et al. 1997; LeeJahnke 2005; 2010; Garbovskiy, Kostikova et al. 2010; Hajrullin 2010; Minčenkov 2008; Širjaev 1979; Voskobojnik 2004).

Philosophers also turned to translation, since many philosophical categories and methods of philosophical perception of reality, such as freedom and necessity, freedom of choice, the absolute and the relative, the conscious and the unconscious, cognition, imagination, will, form and type, probability, associative thinking, the ascent from the abstract to the concrete, dialectics, axiology, interpretation, hermeneutics, and many others constitute the philosophical foundation of translation.

In translation, the problem of choice is primarily a deontological problem of translators' responsibility for their actions. A translator's freedom in the choice of means of expression from a wide range of forms existing in the language, as well as in the choice of the whole translation strategy, is a necessary basis for translation ethics, 
for determination of conditions and the very possibility of critical assessment of his actions (Garbovskiy 2008; Kostikova 2011). If a translator could not have done the way he did, if every decision he made was completely predetermined with no possibility of choice, then it would be impossible to criticize or praise a translator for the work. Thus, no moral assessment of a translator's work would be appropriate or necessary.

The freedom of choice in translation is the core of the most important problem of translation sociology: the problem of a translator's personality and creativity. History of philosophical and philological debates about translation shows that society regularly and consistently blamed translators for their decisions.

Relations between human society and translators have never been easy.

When Cicero explained and justified his translation of Greek orators' speeches into Latin to the critics, he tried to dissociate himself from translation arguing that he treated these speeches not as a translator but as an orator. A few centuries later, Jerome, responding to criticism, on the contrary, compared himself with the Evangelists, who had made different interpretation of God's messages. Even when translating the Bible, a translator has a choice and his actions are not completely determined. That is why Jerome strongly advocated his right to interpretation and choice. He did not even agree with such an authority as St. Augustine, who under the pressure of public outrage asked him to remove ivy and leave a pumpkin in the Latin version of the Book of Jonah.

The public opinion often believed that a translator was a "traitor" and repeated the centuries-old Italian pun traduttore-traditore. E. Dolet managed to write a great treatise on translation before he was executed by the Inquisition, because they did not agree with his translation solution, thus denying a translator's freedom of choice.

It is not only the freedom of choice in translation and translation axiology that attracts attention of philosophers and sociologists. Researchers of the social function of translation build models of the role relations in translation, considering it not only as an act of communication, but also as an act of mediation (Garbovskiy 2009: 47-51).

Translators' behaviour based on choice is one of the manifestations of their social role. Therefore, to understand the translator's behaviour, it is important to analyze the translator's social role and public expectations determined by the understanding of this role.

This approach to the translator's behaviour breaks the stereotype that the translator's behaviour and decisions depend solely on the symmetry or asymmetry of linguistic, cultural and anthropological phenomena a translator faces. This behavioural stereotype goes back to the age of Enlightenment when the idea of human emancipation was put forward and the dominant function of society over an individual was denied. Maximum freedom of every member of society was to ensure public prosperity. Human society was portrayed as self-regulating interaction of free individuals. Therefore, a translator was considered not as an element or a component of the social system, but as a free individual, limited in his actions by asymmetric linguistic factors only.

While in social sciences the idea of individual freedom as the foundation of society was soon replaced by functional theories that regarded society as a unity that dominated over its constituent parts, in science of translation the opinion that a translator is an element of the social structure was not formed yet. The translator's social function has been determined historically, it consists in serving as a "bridge" that 
provides intercultural and interlanguage communication and, more precisely, in providing understanding when different languages and cultures are brought into contact.

However, this social function of translation, which is, of course, the main one, often conceals another, maybe less obvious function that in many ways determines a translator's behaviour. This function is to indicate the presence of "foreign" and to signal that a society that is a consumer of translation faces the "foreign."

To illustrate this social function of translation one can turn to the Biblical story about Joseph,

And Joseph saw his brethren, and he knew them, but made himself strange unto them

[...] Joseph knew his brethren, but they knew not him. And they knew not that Joseph

understood them; for he spake unto them by an interpreter. ${ }^{18}$ (Genesis, 42:7-23)

Thus, however paradoxical it may sound at first, the function of a translator is not to promote mutual understanding between the "contracting parties" in the context of bilingual communication, but to serve a means of ethnic self-assertion and superiority in the "dialogue" of cultures and peoples and that of keeping a barrier.

The translator's function emphasizes the "difference" between communicants, their ethnic backgrounds that proudly sets out their "national self-consciousness." Nowadays, "the game of an interpreter" can be often seen in communication between heads of states and in society.

The recognition of the social function of translation indicating the presence of "foreign" enables us to take another look at one of the oldest problems in translation theory, i.e. the problem of translation strategy that appeared in debates about the place of a translator in the triad: the author of an original message - a translator - the recipient of a translated message. Over the centuries, linguists, philosophers, writers and critics argued about the place translators should choose and, correspondingly, the strategy of translation that they should follow.

Berman, analyzing translation practice and translation theory in Western cultures, built a model of translation strategy, which he defined by the term "traditional figure of translation." In his model, translation according to Western tradition is characterized by three major features: in terms of culture, to be more precise, cultural anthropology, it is "ethnocentric," in terms of poetics it is hypertextual and in terms of philosophy it is platonic:

Dans ladite figure, la traduction est caractérisée par trois traits. Culturellement parlant, elle est ethnocentreique. Littérairement parlant, elle est hypertextuelle. Et philosophiquement parlant, elle est platonicienne. (Berman 1985: 46)

The researcher noted that in the vast majority of translations that had been carried out over many centuries the ethnocentric and hypertextual strategies had been applied. According to Berman, most translators, writers, publishers, and critics consider this model of translation as normal, even normative, considering it as the only possible (Berman 1985: 48). This translation model includes the adaptation of the original work to the translator's culture and ultimately presenting all "foreign" as something negative or suitable for absorbing in this culture; and Berman contrasted it to the model of "ethical" translation.

Hypertextuality which is manifested in all kinds of imitations, adaptations, renderings, etc., in fact, continues and develops the ethnocentric strategy of translation. Hypertextuality is opposed to the poetic model of translation (Berman 1985: 47). 
It is obvious that the ethnocentric model of translation entirely puts a translator in the host ethnic group and obliterates everything "foreign" in the original message.

This translation model, which was traditionally used in European translations, seems to question the social function of translation as a signal of the "foreign." In fact, it only confirms its presence in translation. Translation indicates the presence of the "foreign." That is why the ethnocentric translations have always been opposed to another model that allows experiencing the "foreign" through translation and makes it one of the sources of ethnographic information.

The social function of translation as an indicator of the "foreign" is revealed in various situations of interaction between ethnic groups, opposing them rather than bringing them closer and reflecting variability and closed nature of societies rather than universal features of the whole open human society.

Platonism of translation as a philosophical idea is based on the theory of supersensual ideas by Plato, Classical Greek philosopher, and his followers. This theory argued that the main subject for cognition was supersensual ideas that constituted the essence of being; in contrast, material objects existed only because ideas were realized in them. Platonic translation based mainly on feeling the source text and the translator's intuition is opposed to "sensible" translation based on knowledge.

Thus, the linguistic paradigm gave rise to a broader system of views on translation that at the turn of $20^{\text {th }}$ and $21^{\text {st }}$ centuries began to form a new scientific paradigm, the cognitive paradigm.

The theory of scientific revolutions by Thomas Kuhn (1962) is not fully applicable to science of translation as to any other science dealing with human and society. Kuhn believed that a scientific revolution occurs when researchers find anomalous properties in the studied object that cannot be accounted for with the help of the paradigm that is currently used for analyzing the object and that serves as a framework for scientific knowledge development. When accumulated knowledge on phenomena that cannot be explained within the current paradigm gather critical mass, a scientific discipline goes through a crisis. In a crisis, new ideas that have not been taken into account before appear and are verified. As a result, a new scientific paradigm that has its advocates is formed and intellectual struggle between supporters of the new paradigm and advocates of the old one begins.

However, a new paradigm does not necessarily mean that the previous one is completely discarded. The new paradigm is formed and prepared within the old one, it does not appear out of nowhere as a result of a flash of inspiration or a single discovery. In the humanities, new paradigms appear when accumulated knowledge does not allow studying human only from the dominant viewpoint.

\section{Conclusion}

Accumulated knowledge about translation does not allow studying it only from linguistic viewpoint. Translation is considered to be a cognitive activity.

The cognitive paradigm of science of translation focuses on the translator's intelligence, its complex activity of receiving, storing, managing and accumulating information, understanding it and encoding it using a different sign system and, finally, communicating information. 
Obviously, a science that studies translation using such an approach goes beyond linguistics and becomes interdisciplinary.

Unfortunately, philology in Russia is not willing to recognize independence of science of translation as a field of science that has its own specific and complex object, i.e. translation activity. Linguists follow traditions and study translation only in the framework of comparative and contrastive linguistics; and some of those who are still fascinated by the categorical statement by Reformatsky refuse to recognize science of translation and argue that it has never had scientific paradigms.

This approach to translation activity is based on the misconception that translation has solely linguistic nature and on the unwillingness to acknowledge that science of translation has a new paradigm.

It seems that the new cognitive paradigm in science of translation is the third stage of scientific study of translation. Instead of separate theoretical ideas and models of translation there could appear a rigorous scientifically based theory of this intellectual activity that is founded on a firm philosophical basis and takes into account not only linguistic aspects, but also social, psychological, informational and other ones.

\section{NOTES}

1. Посылаю при сем книгу Пуффендорфа, в которой два трактата, первый - о должности человека и гражданина, другой - о вере христианской; но требую, чтобы первый токмо переведен был, понеже в другом не чаю к пользе нужде быть... (Указ Синоду от 11 сентября 1724 г., cited in Kostikova 2009: 5)

2. надлежит в этой книжке, которую ныне переводите, остереца в том, дабы внятнее перевесть, а особливо те места, которые учат как делат; и не надлежит речь от речи хранить в переводе, но точно сенс выразумев, на своем языке уже так писат, как внятнее может быть. (Указ Зотову «Об избегании в будущем ошибок», 25 февраля 1709 г., cited in Kostikova 2009: 5)

3. Для переводу книг нужны переводчики, а особливо для художественных, понеже никакой переводчик, не умея того художества, о котором переводит, перевесть то не может; того ради заранее сие сделать надобно таким образом: которые умеют языки, а художеств не умеют, тех отдать учиться художествам, а которые умеют художества, а языку не умеют, тех послать учиться языкам... Художества же следующие: математическое... - механическое, хирургическое, архитектур цивилис, анатомическое, ботаническое, милитарис и прочия тому подобные. (Указ от 23 января 1724 г. cited in Nelubin and Huhuni 2006: 205)

4. Ода господина Руссо Fortune de qui la main couronne, переведенная г. Сумароковым и г. Ломоносовым. Любители и знающие словесные науки могут сами по разному сих обеих пиитов свойству каждого перевод узнать.

5. повысить уровень переводческого искусства и подготовить кадры молодых переводчиков, которые могли бы дать новому советскому читателю, впервые приобщающемуся к культурному наследию всех времен и народов, лучшие книги, какие только есть на земле. (Čukovsky 1968: 6)

6. теория художественного перевода, вооружающая переводчика простыми и ясными принципами, дабы каждый - даже рядовой - переводчик мог усовершенствовать свое мастерство. (Čukovsky 1968: 6)

7. почти все переводы нужно делать заново, на других - строго научных - основаниях, исключающих прежние методы беспринципной кустарщины. (Čukovsky 1968: 6)

8. Теоретическая разработка вопросов художественного перевода еще только начинается [...]. Вероятно, ряд положений и оценок К.И.Чуковского вызовет споры, но и могущая возникнуть на этой основе полемика сыграет свою положительную роль, содействуя развитию новой, не разработанной еще области теории литературы. The foreword is anonymous. Čukovsky refers to his book Iskusstvo perevoda [Art of Translation], published in 1936, in Vyssokoe iskusstvo [Art of excellence], published in 1968, in the chapter Biographia knigi [Biography of the book]. 
9. Всякого рода исследования и рассуждения о том, как отразилось при переводе содержание подлинника и какую роль оно сыграло для данной литературы, будут беспредметны, если не будут опираться на анализ языковых средств выражения, использованных при переводе. (Fjodorov 1953: 14)

10. обобщать выводы из наблюдений над отдельными частными случаями перевода и служить теоретической основой для переводческой практики, которая могла бы руководствоваться ею в поисках нужных средств выражения и выбора их и могла бы черпать в ней доводы и доказательства в пользу определённого решения конкретных вопросов. (Fjodorov 1953: 12)

11. Лингвистический разрез в изучении перевода имеет то важнейшее преимущество, что он затрагивает самую его основу - язык, вне которого неосуществимы никакие функции перевода - ни общественно-политическая, ни культурно-познавательная его роль, ни его художественное значение и т.д.. (Fjodorov 1953: 14)

12. [...] которые исключали бы субъективный произвол переводчика и ссылки на “интуицию,” как оправдание переводческого произвола. (Fjodorov 1953: 12)

13. поскольку перевод всегда имеет дело с языком, всегда означает работу над языком, постольку перевод всего больше требует изучения в лингвистическом разрезе - в связи с вопросом о характере соотношения двух языков и их стилистических средств. (Fjodorov 1953: 13)

14. Такой науки быть не может. Практика перевода может пользоваться услугами многих наук, но собственной науки иметь не может. Это вытекает из разнообразия типов и жанров перевода. (Reformatsky 1952: 14)

15. Можно изучать фразеологию романтизма, сентиментализма, натурализма, фразеологию Гоголя, Герцена, Чехова. Так как при таком изучении не только описывается наличие тех или иных фактов, но ставится вопрос о выборе и использовании лексики, то тем самым изучение этого отходит в область стилистики. (Reformatsky 1947/2006: 132)

16. в связи с вопросом о характере соотношения двух языков и их стилистических средств (Fjodorov 1953: 13)

17. Практическое значение этой теоретической науки не в том, конечно, чтобы давать переводчикам советы или - того хуже - рецепты и предписания; она может им быть полезна иначе - лишь опосредованным путем, то есть раскрывая многообразие отношений между разными языками и литературами, разнообразие стилистических возможностей и богатство того языка, на котором делается перевод, широту в выборе средств, предоставляемых им в распоряжение переводчика, указывая на отрицательный эффект, производимый дословным следованием языковым особенностям подлинника, на взаимосвязь и различие между методами перевода и методами оригинального творчества, и многое еще другое. (Fjodorov 1973: 49)

18. Genesis, 42:7-23. King James Version. Christ Unlimited Ministries, Online Bible Church. Visited on 15 March 2012, http://bibleontheweb.com/Bible.asp.

\section{REFERENCES}

Alekseev, Mihail (1931): Problema hudožestvennogo perevoda [Problem of Literary Translation]. Sbornik trudov Irkutskogo gosudarstvennogo universiteta. 18(1):149-196.

Alekseeva, Irina (2004): Vvedenie v perevodovedenie [Introduction to Translatology]. Moscow: Academia.

AwAÏss, Henri (2006): Je dis la «Traductologie» sans que j’en susse rien. In: Michel BALlarD, ed. Qu'est-ce que la traductologie? Arras: Artois Presses Université, 13-22.

BAllard, Michel, ed. (2006): Qu'est-ce que la traductologie? Arras: Artois Presses Université.

Bell, Roger (1991): Translation and Translating: Theory and Practice. London/New York: Longman.

Berman, Antoine (1985): La traduction et la lettre ou l'auberge du lointain. In: Antoine Berman, ed. Les tours de Babel, essais sur la traduction. Mauvezin: Trans-Europ-Repress, 35-150.

Bocquet, Claude (2006): La traductologie: préhistoire et histoire d'une démarche épistémologique. In: Michel BAllard, ed. Qu'est-ce que la traductologie? Arras: Artois Presses Université, 23-36. 
Čennov, Gelij (1978): Teoria i praktika sinkhronnogo perevoda [The Theory and Practice of Simultaneous Interpreting]. Moscow: Meždunarodnye otnošenija.

Čuкоvsкy, Kornej (1936): Iskusstvo perevoda [Art of Translation]. Moscow/Leningrad: Akademia.

Čuкоvsкy, Kornej (1968): Vysokoe iskusstvo [High Art]. Moscow: Sovetskij pisatel'.

Čukovsky, Kornej, Gumilev, Nikolaj and BAtjuškov, Fjodor (1919): Principy xudožestvennogo perevoda. [Principles of Literary Translation]. Moscow: Vsemirnaja literatura.

Danks, Joseph, Shreve, Gregory, Fountain, Stephen, et al., eds. (1997): Cognitive Processes in Translation and Interpreting. Thousand Oaks: SAGE Publications.

EткіND, Efim (1959): Perevod i sopostavitelnaja stilistika [Translation and Comparative Stylistics]. In: Pavel Anтокоц’sкij, Valentina Dynnik, Ivan KašKin, et al., eds. Masterstvo perevoda. Moscow: Sovetskij Pisatel', 71-78.

EткіND, Efim (1970): Hudožestvennyj perevod: iskusstvo i nauka [Literary Translation: Art and Science]. Voprosy jazykoznania. 4:15-29.

Fjodorov, Andrej (1953): Vvedenie v teoriu perevoda [Introduction to the Theory of Translation]. Moscow: Izdatel'stvo literatury na inostrannyh jazykah.

Fjodorov, Andrej (1973): Iskusstvo perevoda i žizn' literatury [Art of translation and life of literature]. Leningrad: Sovetskij Pisatel'.

Fjodorov, Andrej (2002): Osnovy obščej teorii perevoda. Lingvističeskie aspecty. [Foundations fundamentals of general theory of translation. Linguistics Aspects]. Moscow: Filologia Tri.

GaL, Nora (1972/2007): Slovo živoe i mertvoe. [A Word, lively and lifeless]. Moscow: Vremia.

Gambier, Yves, Gile, Daniel and Taylor, Christopher, eds. (1997): Conference Interpreting: Current Trends in Research. Amsterdam/Philadelphia: John Benjamins.

Garbovskiy, Nikolay (2004): Teoria perevoda [Theory of Translation]. Moscow: Moscow State University.

GARBovskiY, Nikolay (2008): Teoria perevoda. Vek XXI: ot empirisma k racionalismu [Theory of Translation. The 21st Century: from Empiricism to Rationalism]. Vestnik Moskovskogo Universiteta. Seria 22. Teoria perevoda. 1:29-47.

Garbovskiy, Nikolay (2009): Dimension sociologique de l'activité de traduction. In: Tatiana Miliaressi, ed. La traduction: philosophie, linguistique et didactique. (Colloque international "La traduction: philosophie, linguistique et didactique," Lille, 1-3 avril 2009). Lille: Université Charles de Gaulle - Lille 3, 47-51.

Garbovskiy, Nikolaj K. and Kostikova, Ol'ga (2011): Dimension sociologique de l'activité traduisante. In: Christian Berner and Tatiana Milliaressi, eds. La traduction: philosophie et traduction - Interpréter/traduire. Villeneuve d'Ascq: Presses Universitaires du Septentrion, 134-136.

Garbovskiy, Nikolay, Kostikova Olga, Mishrurov Eduard, et al. (2010): Nauka o perevode segodnja [Science of Translation Today]. In: Nikolay GarbovsкiY, Olga Kostikova and Ludmila Mozgovaya, eds. Trudy Vysšej Školy Perevoda (fakulteta). 2005-2010. Moscow: U Nikitskih vorot, 9-313.

Goffin, Roger (2006): Aux origines du néologisme traductologie. In: Martine BraCops, AnneÉlizabeth DAlcQ, Isabelle Goffin et al. Des arbres et des mots - Hommage à Daniel Blampain. Bruxelles: Éditions du Hazard, 97-106.

HajRullin, Vladimir (2010): Perevod i frejmy [Translation and Frames]. Moscow: URSS.ru.

HoLmes, James Stratton (1972): The name and nature of translation studies. In: James S. Holmes, ed. (1988) Translated! Papers on Literary Translation and Translation Studies. Amsterdam: Rodopi.

Judin, Erik (1978): Sistemnij podhod i princip dejatel'nosti [The System Approach and The Principle of Activity]. Moscow: Nauka.

Komissarov, Vilen (2001): Sovremennoe perevodovedenie [Contemporary Translation Studies]. Moscow: ETS. 
Kostikova, Olga (2009): Perevod i razvitie russkoj slovesnosti v epohu Petrovskih reform [Translation and the Development of Russian Language in the Age of Peter the Great]. Vestnik Moskovskogo Universiteta. Seria 22. Teoria perevoda. 1:3-9.

Kostikova, Olga (2011): Deontologija perevodčeskoj dejatelnosti [Deontology in Translators Activity]. In: Russkij Jazyk v sovremennom mire: tradicii i innovacii v prepodavanii russkogo jazyka kak inostrannogo i perevoda [Russian language in the modern world: Tradition and Innovation in Teaching Russian as a foreign language and in translation]. (II Meždunarodnaja naučno-praktičeskaya konferencia [2nd International Scientific Conference], Thessaloniki, 25-28 april 2011). Moscow: U Nikitskih Vorot, 368-374.

KRINGs, Hans Peter (1986): Was in den Köpfen von Übersetzern vorgeht: Eine empirische Untersuchungzur Struktur des Übersetzungsprozesses an fortgeschrittenen Französischlernern. Tübingen: Narr Verlag.

Kunn, Thomas Samuel (1962): The Structure of Scientific Revolutions. Chicago: University of Chicago Press.

LADMIRAL, Jean-René (1997): Les quatre âges de la traductologie - Réflexions sur une diachronie de la théorie de la traduction. In: L'histoire et les théories de la traduction - Actes du colloque de Genève. (L’histoire et les théories de la traduction, Genève, 3-5 octobre 1996), Berne/ Genève: ASTTI/ETI, 11-42.

LADMiraL, Jean-René (2004a): La traductologie au XXI ${ }^{\mathrm{e}}$ siècle: de la linguistique à la psychologie. In: Tonia Nenopoulou, ed. Traduire au xxième siecle: Tendances et perspectives. Actes du colloque international. (Traduire au xxième siecle: Tendances et perspectives, Thessalonique, 27-29 septembre 2002). Thessalonique: Faculté des Lettres de l'Université Aristote de Thessalonique, 336-346.

Ladmiral, Jean-René (2004b): Dichotomies traductologiques. La linguistique. 1(40):25-50.

LeE-Jahnke, Hannelore (2005): Processes and Pathways in Translation and Interpretation. Meta. 50(2):337-794.

Lee-Jahnke, Hannelore (2010): Trendsetters \& Milestones in Interdisciplinary Process-oriented translation: Cognition, Emotion, Motivation. In: Martin Forstner and Hannelore LeEJAHNKE, eds. CIUTI Forum 2010 - Global Governance and Intercultural Dialogue: Translation and Interpreting in a new geopolitical Setting. Bern: Peter Lang, 109-151.

LÉvi-STrauss, Claude (1958/1974): Anthropologie structurale. Paris: Plon.

Ljubimov, Nikolaj (1977): Perevod - iskusstvo [Translation, An Art]. Moscow: Sovetskaja Rossia. Malblanc, Alfred (1961): Stylistique comparée du français et de l'allemand. Paris: Didier.

MinčEnkov, Alexej (2008): Kognitivno-evrističeskaya model' perevoda [Cognitive and Heuristic Model of Translation]. Doctoral thesis, unpublished. Saint-Petersburg: Saint-Petersburg State University.

Montesquieu, Charles-Louis (1875): Lettres Persanes. Paris: Garnier Frères.

Mounin, Georges (1963): Les problèmes théoriques de la traduction. Paris: Gallimard.

Nelubin, Lev and Huhuni, Georgij (2006): Nauka o perevode [Science of Translation]. Moscow: Flinta.

OSEKI-DÉPRÉ, Inês (1999): Théories et pratiques de la traduction littéraire. Paris: Armand Colin.

Reformatsky, Alexander (1947/2006): Vvedenie v yazykovedenie [Introduction to linguistics]. Moscow: Aspekt-Press.

Reformatsky, Alexander (1952): Lingvističeskie voprosy perevoda [Linguistic Issues of Translation]. Inostrannye jazyki $v$ škole. 6:12-22.

Sdobnikov, Vadim and Petrova, Olga (2007): Teoria perevoda. Učebnik dlia studentov lingvističeskih vuzov i fakultetov inostrannyh jazykov [Theory of Translation. Textbook for students of linguistic universities and foreign language faculties]. Moscow: AST/VostokZapad.

ŠIRJAeV, Alexander (1979): Sinhronnij perevod [Simultaneous Interpreting]. Moscow: Voenizdat. Steiner, Georges (1978): Après Babel. Paris: Albin Michel.

Sumarokov, Alexandr (1957): Epistola I <o russkon yazyke> [Epistle I <on Russian Language >]. In: Alexandr Sumarokov. Stihotvorenia [Poems]. Moscow: Sovetskij Pisatel'. 
Tirkkonen-Condit, S. (1989): Professional Versus Non-Professional Translation: A ThinkAloud protocol study. In: Candace Séguinot, ed. The Translation Process. Toronto: H.G. Publications, 73-84.

Toper, Pavel (2000): Perevod v sisteme sravnitel'nogo literaturovedenia [Translation in the System of Comparative Literature Studies]. Moscow: Nasledie.

Tulenev, Sergej (2004): Teoria perevoda [Theory of Translation]. Moscow: Gardariki.

Vinay, Jean-Paul et Darbelnet, Jean (1958): Stylistique comparée du français et de l'anglais. Montréal: Beauchemin.

Vosковолмік, Grigorij (2004): Lingvofilosofskie osnovania obščej kognitivnoj teorii perevoda [The Linguistic and Philosophical Base of General Cognitive Theory of Translation]. Doctoral thesis, unpublished. Irkutsk: Irkutsk State Linguistic University.

Wu, Qing (2002): Interaction Between Language and the Mind Through Translation: A Perspective from Profile/Base Organization. Meta. 47(4): 532-563. 